А. В. Ковальова

Київський національний університет будівництва і архітектури, Київ, Україна

\title{
ВИРОБНИЧИЙ РИЗИК ВІД ПОСТІЙНОГО ШУМОВОГО НАВАНТАЖЕННЯ ДЛЯ РОБІТНИКІВ ВІДКРИТОГО ПОВІТРЯ
}

\begin{abstract}
Анотація. Представлене дослідження стосується визначення безпеки працюючих на відкритому повітрі при ремонті та реконструкції автомобільних шляхопроводів та будівельних робіт поблизу автомагістралей в умовах постійного шумового навантаження. На підставі аналізу вітчизняних та нормативних досліджень було визначено методологію досліджень виробничого ризику в залежності від вікової категорії працюючих та їх професійного стажу. Предметом дослідження $є$ вплив постійного шумового забруднення на безпеку працюючих відкритого повітря для умов м. Києва. Мета роботи - визначення комплексного виробничого ризику від постійного шумового забруднення для безпеки працівників відкритого повітря. При визначенні сукупного значення виробничого ризику, розглядалися окремо значення ризику захворювання серцево-судинної системи, ризику захворювання нервової системи та ризик захворювання органів слуху. Завдання роботи - на підставі натурних вимірів по обраних автомобільних шляхопроводах та великих перехрестях в залежності від кількості полос руху в м. Києві, здійснено аналіз рівнів постійного шумового навантаження на території виробничих майданчиків працюючих. Встановлено межі шумового навантаження, що у більшості середньозважених та у максимальних значеннях вимірів перевищують нормативний рівень відкритого виробничого майданчика (80дБА). Методи досліджень: натурні виміри здійснювалися прибором «Асистент», методи розрахунку здійснювалися на основі методик діючих міжнародних стандартів та нормативних документів. Наукова новизна полягає в оцінці величин виробничого ризику для умов м. Києва для працюючих на відкритому повітрі від постійного шумового навантаження на протязі 8-годинного робочого дня в залежності від вікових показників та професійного стажу. Отримані результати щодо оцінки ризику сукупного рівня захворювань в залежності від рівнів шуму на автомобільних шляхопроводах м. Києва, свідчать про середній (помірний рівень) для різних вікових груп працюючих. Що стосується значення сукупного агрегованого ризику у випадку максимальних рівнів шумового забруднення, то розрахунки показали, що у випадку працюючих за віком більше 50 років ризик кваліфікується, як високий. Висновки досліджень свідчать, що отримані результати середньозважених і максимальних рівнів шумового забруднення для безпеки працюючих на відкритому повітрі потребують заходів по зниженню шумового навантаження, які слід розробляти з врахуванням середньострокової та короткострокової перспективи (1-3 роки), а також щорічний перегляд значень виробничого ризику.
\end{abstract}

Ключов і слова : ризик, оцінка ризику, автошляхопровід, будівельні роботи, діючі стандарти, рівень шумового забруднення, на основі отриманих даних в м. Києві.

\section{Вступ}

В рамках імплементації природоохоронного законодавства України з законодавством Свропейського Союзу наша держава зробила досить істотні кроки в напрямку запозичення досвіду держав-партнерів щодо удосконалення державного екологічного управління. Але на сьогоднішній день порівняльний аналіз чинної законодавчої бази України та міжнародних стандартів і Директив СС свідчить про відставання у цьому питанні по деяких нормах та стандартах, які діють ще на рівні ГОСТів з радянських часів. Не виключення в цьому питанні складають також нормативні документи, які стосуються визначення виробничого ризику працюючих як на виробництві, так i на відкритому повітрі. Поставлена мета статті на основі аналізу вітчизняних та міжнародних нормативних документів і отриманих виміряних даних шумового забруднення на основних перехрестях м. Києва визначити виробничий ризик від постійного шумового забруднення для безпеки працівників відкритого повітря.

Аналіз існуючих досліджень. На даний час багато дослідників відзначали розбіжності при порівняльному аналізі національної та міжнародної нормативної бази, зокрема також документів, що стосуються безпеки працюючих на відкритому повітрі. Як зазначають автори роботи [1], аналіз нормативних даних щодо шумового забруднення на територіях житлових забудов, в тому числі від автотранспортних засобів урбанізованих територій потребує більш жорстких вимог до додержання нормативів щодо рівнів шумового забруднення. На основі аналізу діючих національних та міжнародних норм та стандартів, автори роботи вважають, етап імплементації європейського законодавства в умови українських виробників має визначити процедуру положення Директиви 2002/49/СС, яка стосується створення основ для розробки ряду заходів, що націлені на скорочення шумового впливу від основних джерел на урбанізованих територій, в т.ч. автотранспортними засобами. Загальний підхід, який прописаний даною Директивою, спрямований на рекомендації щодо визначення впливу шуму навколишнього середовища за допомогою картографування; забезпечення того, щоб інформація про екологічний шум та його наслідки була доступною для громадськості; прийняття державами-членами ЄС планів дій, заснованих на результатах картографування шуму [2].

Працівники відкритого повітря, зокрема автодорожньої галузі знаходяться під впливом постійного шумового навантаження від автотранспортних засобів на протязі 8 - часового робочого дня, тому з деяким запасом оцінку порушень для здоров'я працюючих можна приймати за матеріалами документів [3-6], а саме: нервова система (порогові рівні шуму від 35Дб для нервової напруги до 60 Дб щодо порушень вегето-судинної дистоніі); система кровообігу (порогові рівні шуму від збільшення кров'яного тиску без діагнозу гіпертонії від 
65Дб до 70дБ щодо стенокардії та інфаркту міокарду); хвороби вуха (порогові дані від 45дБ шуму в ухах до 80дБ щодо втрати чутливості внаслідок впливу шуму).

\section{Виклад основного матеріалу}

Методологія оцінки ризику здоров'ю населення від впливу транспортного шуму пропонується виконувати у відповідності за Методичними рекомендаціями МР2.110.0059-12 «Оцінка ризику здоров'я населення від впливу транспортного шуму» [7]. В якості основної одиниці щодо рівня шумового забруднення при виконанні оцінки ризику пропонується використовувати показник еквівалентного рівня середньозваженого добового шуму (Lden) з врахуванням як денних, так і нічних рівнів. Рекомендації цього документу стосуються населення, які піддається постійному впливу шумового забруднення від автотранспортних засобів, як, наприклад, мешкання в будівлях поблизу напруженої автотраси.

Рекомендації міжнародного стандарту ISO 1999:2013 можуть бути застосовані безпосередньо для визначення впливу шумового забруднення для працівників відкритого повітря [8]. Стандарт ISO 1999:2013 визначає метод для розрахунку очікуваного постійного зсуву порогу, викликаного шумом, у порогових рівнях чутності дорослого населення через різні рівні та тривалість впливу шуму; він $\epsilon$ основою для розрахунку порушення слуху, коли порогові рівні чутності на загально вимірюваних аудіометричних частотах або комбінаціях таких частот перевищують певне значення. Стандарт може застосовуватися для розрахунку імовірності втрати чутливості внаслідок регулярного впливу виробничого шуму.

Категорія працівників, що розглядається в даній статті - працюючі по ремонту автодорожних шляхів та будівельних робіт поблизу автомагістралей. Показником впливу шуму на групу ризику є рівень шумового впливу, нормований на номінальний 8-годинний робочий день для заданої кількості років впливу. Дія ISO 1999:2013 поширюється на шум на частотах менше ніж приблизно 10 кГц, який є постійним, переривчастим, коливання, нерегулярним.

В Україні на сьогоднішній день діють національні стандарти ДБН В.1.1-31:2013 «Захист територій, будинків і споруд від шуму» та ДСТУ-Н Б В.1.133:2013 «Настанова з розрахунку та проектування захисту від шуму сельбищних територій» [9-10], які містять розрахунки шуму на сельбищних, ландшафтнорекреаційних територіях та інших територіях 3 нормованими рівнями шуму, в приміщеннях житлових і громадських будинків від потоків автомобільного i залізничного транспорту, поїздів наземного метро, потоків трамваїв, авіаційного і водного транспорту, від локальних внутрішньоквартальних джерел шуму

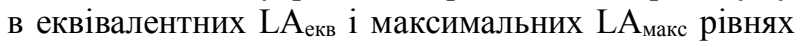
звуку в дБА.

Аналіз вітчизняних та міжнародних нормативних документів щодо даних шумового забруднення, свідчить про те, що значення допустимої експозиції шумового забруднення протягом 8-часового робочого дня знаходиться в межах від 75дБА (Рекомендації Агентства 3 охорони навколишнього середовища США та Всесвітньої організації охорони здоров'я щодо шуму в громаді) до 90 дБА (допустима межа впливу за рекомендаціями Управління 3 охорони праці та гігієни США) [11]. Враховуючи вітчизняну та міжнародну нормативну базу з даного питання, автори роботи вважають при розрахунку ризику працюючих на відкритому повітрі від постійного шумового навантаження слід застосовувати методику згідно Методичних рекомендацій МР 2.1.10.0059-12, але при цьому рівень діючого рівня шуму приймати за рекомендаціями міжнародного стандарту ISO 1999:2013 для 8-годинного робочого дня або за виміряними даними по основних автошляхопроводах м. Києва.

\section{Матеріали досліджень}

На 10 найбільш навантажених автомобільних розв'язках м. Києва були здійснені заміри шумового навантаження вимірювачем рівня звуку «Ассистент». Вибір точок для дослідження здійснювався в залежності від кількості автомобільних з врахуванням автомобільної розв'язки та кількості транспортних засобів, які одночасно перебувають на даній території. Виконані заміри показали, що в більшості випадках шум на великих автошляхопроводах м. Києва знаходиться в межах від 68 дБА до 90,72 дБА, що перевищує значення 80 дБА , яке $\epsilon$ критичним рівнем для значення виробничого ризику працюючих. В результаті проведених досліджень нами враховувалося положення, яке приведено авторами в роботі [12]. На основі кореляційних залежностей автори роботи довели, що за поточних параметрів транспортного потоку (високої інтенсивності руху зі значною перевагою у структурі транспортного потоку легкових автомобілів) на еквівалентний рівень звуку впливає загальна кількість автомобілів, тоді як вплив окремих груп інших видів транспорту (вантажних, автобусів та мікроавтобусів тощо) незначне.

Методологія оцінки ризику здоров'ю визначалася нами на основі рішення наступних рівнянь, які враховують оцінку агрегованого ризику порушення серцево-судинної, нервової системи та органів слуху відповідно [7]:

$$
\left\{\begin{array}{c}
R_{t+1}^{A c n}=R_{t}^{A c n}+\left[0,0118 \cdot R_{t}^{A c n}+0,001 \cdot\left\langle\frac{L_{\text {den }, t} \cdot\left(1-R_{t}^{A c n}\right)}{50}-1\right\rangle\right] C \\
R_{t+1}^{A c n}=R_{t}^{A c n}+\left[0,052 \cdot R_{t}^{A c n}+0,015 \cdot\left\langle\frac{L_{\text {den }, t} \cdot\left(1-R_{t}^{A c n}\right)}{58,5}-1\right\rangle\right] C \\
R_{t+1}^{A c n}=R_{t}^{A c n}+\left[0,0074 \cdot R_{t}^{A c n}+0,0016 \cdot\left\langle\frac{L_{d e n, t} \cdot\left(1-R_{t}^{A c n}\right)}{43}-1\right\rangle\right] C .
\end{array}\right.
$$

В даних рівняннях:

$R_{t}^{A_{i}}-$ ризик порушення і-тої системи органів на початковій (заданій) в момент часу $\mathrm{t}$;
$R_{t+1}^{A_{i}}$ - ризик порушення і-тої системи органів для наступного часового періоду $(\mathrm{t}+1)$ (залежить від $C$ ); 
$R_{t}^{A_{\text {сл }}}$-агрегований ризик розвитку порушень різної важкості слухового апарату (шум у вухах кондуктивна нейросенсорна втрата слуху, т втрата слуху, викликана шумом) на момент часу $\mathrm{t}$;

$R_{t}^{A_{\text {cс }}}-$ агрегований ризик розвитку порушень різної важкості серцево судинної системи, підвищеного тиску, гіпертензивна та ішемічна, хвороба серця, стенокардія, інфаркт міокарда викликані шумом на момент t;

$R_{t}^{A_{\text {нс }}}$ - агрегований ризик розвитку в момент $\mathrm{t}$ порушень нервової системи (нервове напруження, порушення сну, когнітивні порушення, вегето-судинна дистонія);

$L_{d e n, t}-$ середньозважений добовий рівень шуму у досліджуваний період $\mathrm{t}$, (дБ);

$\mathrm{C}$ - часовий емпіричний коефіцієнт; \langle\rangle - дужки Келлі приймаюче значення $\langle x\rangle=0$ при $x<0$ та $\langle x\rangle=x$, при $x \geq 0$.

В табл. 1 представлено розрахунок по агрегативному ризику, який був розрахований за системою рівнянь (1) для різних вікових груп працюючих для двох перехрестів по середньозваженому та максимальних значеннях виміряного шумового забруднення.

Таблиця 1 (рівень визначення класифікації ризику для працюючих на відкритому повітрі від шумового навантаження) представлена в робочих позначках на перехресті Чоколівський бульвар - Повітрофлотський проспект за величиною середньозваженого рівня шуму і перехресті пр. Перемоги - вул. Олекса- ндра Довженка (район Шулявського мосту) за величиною максимального виміряного рівня шуму. Класифікація рівнів ризику розміщена в Методичних рекомендаціях МР2.110.0059-12 [7].

Дані розрахунків виробничого ризику для інших найбільш великих перехрестів показали, що сукупний ризик від шумового забруднення знаходиться в тих же межах, що і приведений приклад у табл. 1. Розрахунки за даною методикою показали середній (помірний) рівень сукупного ризику від шумового забруднення при середньозважених значення вимірів для всіх вікових груп працюючих; при максимальних вимірах шумового навантаження ризик класифікується як високий для груп працюючих після 50 років. При дії довготривалого шумового навантаження при розрахунку загального значення ризику слід враховувати втрату чутності працюючих в залежності від стажу роботи. Так розрахунки за методикою ISO 1999:2013 засвідчили, що при 30-літньому професійному стажі та рівні шумового впливу за 8 годинний робочий день $L_{\mathrm{EX}, 8 \mathrm{~h}}=90$ дБ імовірність втрати чутності для 50 річних працюючих складає 11,5\% при 10\% зміщенні порогу чутності; для 40 річних працюючих ці цифри складають відповідно 7\% і 6,8\%. Виходячи 3 даних міркувань при визначенні комплексного ризику від всіх впливових факторів на безпеку працюючих на відкритому повітрі слід враховувати також додатково такий показник, як втрата чутності від постійного шумового навантаження.

\section{Таблиця 1 - Рівень визначення класифікації ризику}

\begin{tabular}{|c|c|c|c|c|}
\hline $\begin{array}{l}\text { Вік } \\
\text { працівника }\end{array}$ & $\begin{array}{l}\text { Ризик захворювання } \\
\text { органів слуху }\end{array}$ & $\begin{array}{c}\text { Ризик захворювання } \\
\text { серцево-судинної } \\
\text { системи }\end{array}$ & $\begin{array}{c}\text { Ризик захворювання } \\
\text { нервової } \\
\text { системи }\end{array}$ & $\begin{array}{l}\text { Сукупний ризик } \\
\text { захворювань }\end{array}$ \\
\hline \multicolumn{5}{|c|}{ 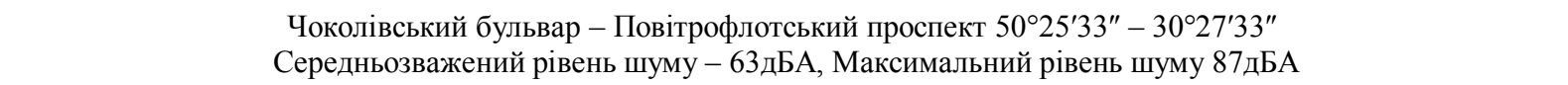 } \\
\hline 20 & 0,0230 низький & 0,007 низький & 0,02855 низький & 0,0585 помірний \\
\hline 30 & 0,0258 низький & 0,0121 низький & 0,0330 низький & 0,070 помірний \\
\hline 40 & 0,0290 низький & 0,0201 низький & 0,0353 низький & 0,084 помірний \\
\hline 50 & 0,0323 низький & 0,0515 помірний & 0,0377 низький & 0,125 помірний \\
\hline 60 & 0,03622 низький & 0,132 помірний & 0,0405 низький & 0,208 помірний \\
\hline \multicolumn{5}{|c|}{$\begin{array}{c}\text { пр. Перемоги - вул. Олександра Довженка (район Шулявського мосту) } 50^{\circ} 27^{\prime} 14^{\prime \prime}-30^{\circ} 26^{\prime} 44^{\prime \prime} \\
\text { Середньозважений рівень шуму - 69дБА, Максимальний рівень шуму 93дБА }\end{array}$} \\
\hline 20 & 0,0230 низький & 0,007 низький & 0,02855 низький & 0,0585 помірний \\
\hline 30 & 0,0348 низький & 0,0221 низький & 0,0512 помірний & 0,070 помірний \\
\hline 40 & 0,0566 помірний & 0,0501 помірний & 0,0798 помірний & 0,1081 помірний \\
\hline 50 & 0,0733 помірний & 0,0615 помірний & 0,113 помірний & 0,2678 помірний \\
\hline 60 & 0,1056 помірний & 0,142 помірний & 0,140 помірний & 0,3888 високий \\
\hline
\end{tabular}

Для визначення умов праці за показниками шкідливості та небезпечності факторів виробничого середовища 3 достатньою точністю на попередньому етапі можна прийняти за документом [13].

\section{Висновки}

На підставі виміряних рівнів шумового забруднення на основних автомагістралях м. Києва було визначено середньозважені і максимальні рівні постійного шумового впливу для працюючих на відкритому повітрі, які задіяні на ремонті та реконструкції автошляхопроводів міста.

Встановлено межі шумового навантаження, що у більшості середньозважених та у максимальних значеннях вимірів перевищують нормативний рівень відкритого виробничого майданчика (80дБА). 
Рівень виробничого ризику за окремими напрямками впливу на здоров'я працюючого (ризик захворювання органів слуху, ризик захворювання серцевосудинної системи, ризик захворювання нервової системи) знаходяться в межах низького $(\mathrm{R}<0,05)$ та помірного $(0,35>R>0,05)$.

Але що стосується значення сукупного агрегованого ризику, то його значення незалежно від віку працюючого знаходиться в межах середнього (помі- рного) ризику, а у випадку працюючих за віком більше 50 років ризик кваліфікується, як високий. В даному випадку рекомендовано застосування заходів для організації постійного моніторингу шумового забруднення; заходи по зниженню шумового навантаження слід розробляти 3 врахуванням середньострокової та короткострокової перспективи (1-3 роки), а також щорічний перегляд значень виробничого ризику.

\section{СПИСОК ЛІТЕРАТУРИ}

1. Решетченко А.І., Борсук А.І., Вергелес Ю.І. Аналіз існуючих нормативів країн ЄС порівняно із вимогами українського законодавства в сфері шумового навантаження в урбоексистемі. Екологічна безпека та збалансоване ресурсокористування. Науково-технічний журнал № 2 (20) 2019, С. 16-23.

2. Директива 2002/49/ЄС Європейського Парламенту. Оцінка та управління процесами, пов'язаними 3 шумом OBL 189 , [чинний від 25 червня 2002 року] 18.07.2002. С. 12.

2. Фридман К.Б., Лим Т.Е., Шусталов С.Н. Концептуальная модель оценки и управления риском здоровью населения от транспортных загрязнений. Гигиена и санитария. 2011. № 3 С. 20 - 25.

3. Haralabidis A.S., Dimakopoulou K., Vigna-Taglianti F., Giampaolo M., Borgini A., Dudley M.-L., Pershagen G., Bluhm G., Houthuijs D., Babisch W., Velonakis M., Katsouyanni K., Jarap L. Acute effects of night-time noise exposure on blood pressure in populations living near airports. European Heart Journal, 2008. pp. 658-664.

4. Prasher D., Environmental Noise and Health: The Latest Evidence. 2002. pp. 151-155.

5. Haines M.M., Brentnall S., Stansfeld S.A, Klineberg E. Qualitative responses of children to environmental noise. Noise \& Health, vol. 5, № 19, 2003. pp. 19-30.

6. Онищенко Г.Г., Аксенова О.И., Гуськов А.С., Черненко С.М. Оценка риска для здоровья населения от воздействия транспортного шума : Методические рекомендации. Федеральный центр гигиены и эпидемиологии Роспотребнадзора, Москва, 2012. С. 40.

7. ISO 1999:2013(E). International Standart. Acoustics - Estimation of noise-induced hearing loss. DOI: https:/www.iso.org/ru/standard/45103.html

8. ДБН В.1.1-31:2013 Захист територій, будинків і споруд від шуму. [На зміну СНиП ІІ-12-77; чинний від 01.06.2014] Київ: Мінрегіон України. 2014. С. 85.

9. ДСТУ-Н Б В.1.1-33:2013 Настанова з розрахунку та проектування захисту від шуму сельбищних територій. Київ: Мінрегіон України, 2014. $46 \mathrm{c}$.

10. Neitzel R., Fligor B., Determination of risk of noise-induced hearing loss due to recreational sound: Review Who, 2017.- P.25

11. Makarova I., Khabibullin R., Mavrin V., Belyaev E. Simulation modeling in improving pedestrians' safety at non-signalized crosswalks. Transport problems. 2016. Vol. 11, Issue 4, P. 139-150.

12. ГН 3.3.5-8-6.6.1 Гігієнічна класифікація праці за показниками шкідливості та небезпечності факторів виробничого середовища, важкості та напруженості трудового процесу. [чинний від 27.12.2001] Київ. м МОЗ України. 2001. C. $28-34$.

Received (Надійшла) 26.10.2021

Accepted for publication (Прийнята до друку) 24.11.2021

\section{Production risk from constant noise load for open air workers}

\section{A. Kovalova}

Abstract. The presented research concerns the determination of the safety of workers in the open air during the repair and reconstruction of highways and construction works near highways under conditions of constant noise load. Based on the analysis of domestic and regulatory research, the methodology of research on industrial risk within the age categories of employees and their professional experience was determined. The subject of the study is the impact of constant noise pollution on the safety of workers working outdoors for the conditions of Kyiv. The aim of the work is to determine the complex industrial risk of constant noise pollution for the safety of workers working outdoors. In determining the total value of occupational risk, the values of cardiovascular disease risk, nervous system disease risk and hearing risk were considered separately. The task of the article is on the basis of field measurements on selected highways and large intersections depending on the number of lanes in Kyiv, the analys is of levels of constant noise load on the production sites of workers. Noise load limits have been set, which in most weighted averages and in the maximum values of measurements exceed the normative level of the open production site ( $80 \mathrm{dBA})$. Research methods: field measurements were performed with the device "Assistant", calculation method - based on the methods of current international standards and regulations. The scientific novelty is to assess the magnitude of industrial risk for the conditions of the city of Kyiv for workers in the open air from the constant noise load during the 8-hour working day, depending on age and professional experience. The obtained results on the assessment of the risk of the total level of diseases depending on the noise levels on the highway overpasses of Kyiv, indicate an average (moderate level) for different age groups of workers. Regarding the value of the aggregate aggregate risk in the case of maximum levels of noise pollution, the calculations showed that in the case of workers over the age of 50 the risk is classified as high. The results show that the results of the weighted average and maximum levels of noise pollution for the safety of workers working outdoors require noise reduction measures, which should be developed taking into account the medium and short-term (1-3 years) and an annual review of industrial risks.

Keywords : risk, risk assessment, highway overpass construction works, current standards, noise pollution level, based on the data obtained in Kyiv. 